\title{
Örtmeceli Küfürlerin Görsel-İşitsel Çevirisinde Soru ve Sorunlar: İyi Yer Örneği
}

\author{
DR. AYSUN KIRAN* - DOÇ. DR. DERYA OĞUZ**
}

\begin{abstract}
Öz
Mizah ve küfür gibi kültüre özgü ögeler, diller arası aktarımlarında ortaya çıkan zorlayıcı yönler ve bunların sonuçları açısından görsel-işitsel çeviri alanında farklı bağlamlar üzerinden çalışılmıştır. Bu çalışmada, bu iki ögenin önemli yer tuttuğu Netflix yapımı Amerikan dizisi İyi Yer (The Good Place) incelenerek sansürlü küfür kullanımının mizah unsuru olarak işlev görmesine odaklanılmıştır. 20162020 yılları arasında yayınlanan dizi, kurmaca dünyasının bir parçası olarak küfür filtresi bulunması ve bunun sonucunda küfürlerin sözcük oyunlarıyla sansüre uğratılması açısından küfür, örtmece ve mizah ögelerini bir araya getirmektedir. Bu açıdan, dizideki küfür filtresi, yaratıcı dil kullanımının görsel-işitsel alanda çeviri yoluyla yeniden üretimi üzerinde rol oynayan faktörleri tartışma olanağ1 sunmaktadır. Çalışmamızın amacı, kaynak metindeki örtmeceli küfürlerin Türkçe çevirisinde ne tür yollar izlendiğini tespit etmek ve bu küfürlerin dizinin kurmaca dünyasındaki anlamlandırmalarının erek metinde ne ölçüde aktarıldığını incelemektir. Bunu yaparken İyi Yer'deki sansürlü küfürlerin görsel-işitsel çevirisinde verilen kararları incelemek adına dizinin İngilizce orijinali ile altyazı ve dublaj çevirisi karşılaştırılacaktır. Örtmeceli küfürlerin hem kaynak hem de erek metinde yeniden modelleme yoluyla oluşturulduğu, ancak Türkçede örtmece oluşturma biçimlerinde dikkat çeken bir tutarsızlık olduğu ve bu tutarsızlıkların küfür filtresinin etkisinin aktarılmasında anlam kaybı ve karakter temsilinde kaymalara neden olduğu tespit edilmiştir. Sözü edilen kaymaların muhtemel nedenleri ve sonuçları yaratım süreçlerindeki farklılıklar, dilsel kısıtlamalar ve bağlamsal faktörler üzerinden tartışlacaktır.
\end{abstract}

Anahtar sözcükler: örtmece, küfür, altyazı çevirisi, dublaj, görsel-işitsel çeviri

\section{THE QUESTIONS AND CHALLENGES IN THE AUDIO-VISUAL TRANSLATION OF EUPHEMISED SWEARINGS: THE CASE OF THE GOOD PLACE}

Abstract

Cultural elements such as humour and swearing have been studied in different contexts in the field of audio-visual translation in terms of the compelling aspects that arise in their interlingual transmission and their results. In this study it is focused on the use of censored swearing as an element of humour by the examination of the Netflix production The Good Place, in which these two elements have an important place. The series, which was broadcast between 2016-2020, combines profanity, euphemism and humour in terms of having a curse filter as a part of the fictional world and as a result censoring curses with word plays. In this respect, the profanity filter in the series offers the opportunity to discuss the factors that play a role in the reproduction of creative language use through translation in

\footnotetext{
* Marmara Üniversitesi, ayskir@gmail.com, orcid 0000-0003-1551-3776

** Marmara Üniversitesi, deryaoguz06@yahoo.com, orcid 0000-0001-5228-076X 
the audio-visual field. The aim of our study is to determine what kind of ways are followed in the Turkish translation of the euphemistic curses in the source text and to examine to what extent the meanings of these curses in the fictional world of the series are conveyed in the target text. While doing this, the English original of the series will be compared with the subtitle and dubbing translation in order to examine the decisions made in the audio-visual translation of the censored curses in The Good Place. It has been determined that euphemistic profanities are formed by remodeling both in the source and target text, but there is a remarkable inconsistency in the forms of euphemism in Turkish, and these inconsistencies cause loss of meaning and shifts in character representation in transferring the effect of the profanity filter. The possible causes and consequences of the mentioned shifts will be discussed through differences in creation processes, linguistic constraints and contextual factors.

Keywords: euphemism, swearing, subtitling, dubbing, audio-visual translation

\section{GİRIŞ}

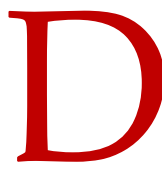

izi ve film gibi görsel-işitsel metinlerde mizah ve küfür, bu metinlerin içinden çıktığı kültüre özgü ögeler taşımaları bakımından görsel-işitsel çeviri alanında tartışılmaya değer iki önemli araştırma konusunu oluşturmaktadır. Literatürdeki örneklerinden farklı olarak bu çalışmada birebir küfür veya mizah çevirisinden çok küfür kullanımının mizah unsuru olarak işlev gördüğü bir görsel-işitsel metnin İngilizceden Türkçeye çevirisine odaklanılmaktadır. Bu bağlamda 2016-2020 yılları arasında yayınlanan Netflix yapımı Amerikan dizisi İyi Yer'deki (The Good Place) örtmeceli küfürlerin görsel-işitsel çevirisi altyazı ve dublaj çevirilerinin karşılaştırmalı analizi üzerinden incelenecektir. Komedi ve fantastik türdeki dizide cennete gittiklerini sanan dört faninin, aslında onlara işkence etmek amacıyla tasarlanmış olan sahte İyi Yer'de başından geçenler ve gerçek İyi Yer'e ulaşma maceraları anlatılmaktadır. İyi Yer isimli mekânın kendine özgü yanlarından birisi, küfretmenin yasak olması ve her küfürlü sözcüğün bir filtreden geçmesidir. Dolayısıyla, küfürlerin dışarıdan uygulanan bir sansür sonucu değil, dizinin kurmaca dünyasına özgü bir özellik olarak örtmeceye uğraması ve bir komedi unsuru oluşturması küfür filtresinin bu yaratıcı metinlerin çevirisinde nasıl uygulandığını incelemeyi önemli kılmaktadır.

Görsel-işitsel metinlerde mizah ve küfür çevirisi farklı bağlamlar üzerinden pek çok çalışmada araştırılmıştır (Chen, 2004; Fernández Dobao, 2006; Ávila-Cabrera, 2015). Frédéric Chaume, görsel-işitsel çevirinin ana işlevinin, kaynak metnin kaynak kültürdeki seyirci üzerinde yarattığına benzer bir etkiyi erek kültürdeki seyirci üzerinde yaratmak olduğunu belirtir (2004, s. 844). Fernández Dobao ise küfür ve benzeri türde müstehcen ifadelerin, bir metinde sıkça kullanıldığı durumlarda o metnin biçemsel belirleyicisi hâline gelebildiğini ve bu tür metinlerin çevirisinde biçemsel eşdeğerliğin sağlanmasının anlamsal eşdeğerlik kadar önem kazandığının altını çizer (2006, s. 223). Buna göre kaynak metindeki biçemsel özellikler, küfür kullanılma sıklığ1 ve gayri resmilik derecesi çeviri sürecinde dikkate alınmalı ve erek metinde bu noktalar muhafaza edilmelidir (a.g.e., s. 223). İyi Yer gibi küfrün örtmeceli olarak kullanıldığı bir görsel-işitsel metnin çevirisinin incelenmesinde ise, kaynak metinde küfrün neden örtmeceye uğratıldı̆̆ı, küfürlerin örtmeceli versiyonlarının nasıl oluşturulduğu, küfür filtresinin karakterlerin kişiliklerine dair ne tür bir bilgi sunduğu ve örtmecelerin dizinin kurmaca dünyasındaki işlevinin saptanması gibi 
noktalar üzerinde durulacaktır. Çalışmamızın amacl, bu filtrenin sonucunda ortaya çıan örtmeceli küfürlerin çevirisinde izlenen yolları tespit etmek ve öne çıan özellikleri betimlemektir. Böylece, bir komedi dizisindeki örtmeceli küfür çevirisi incelenerek kültüre özgü ögelerin aktarılmasında rol oynayan faktörlere dair literatürdeki tartışmalara katkı sunulacaktır.

Giriş bölümünü izleyen ikinci bölüm küfür ve örtmece üzerine bir literatür taraması içermektedir. Buna göre, ilk olarak, küfür işlevleri, tabu ile ilişkisi ve literatürde bu özelliklerin görsel-işitsel metinlerdeki küfür çevirisinde ne şekilde tartışıldığı belirtilecektir. İkinci olarak, örtmece yapılma biçimleri ve işlevleri ayrı bir başlık altında verilerek Iyi Yer'deki örtmece oluşturma biçimi ve bunun Türkçeye aktarılma biçimlerinin önemine dair bir fikir sunulacaktır. Üçüncü bölümde, çalışmamızın odak noktası olan İyi Yer'deki küfür filtresinin özellikleri ve örtmece oluşturma biçimleri İngilizce orijinali ile Türkçe altyazı ve dublaj çevirileri üzerinden karşılaştırılacak, kaynak ve erek metin arasında örtmece oluşturma biçimlerinde ne gibi benzerlikler ve farklılıklar olduğu saptanacaktır. Elde edilen bulgular, dördüncü bölümde, muhtemel sebepleri ve yarattığı sonuçlar üzerinden tartışılacaktır. Bunu yaparken, altyazı ve dublaj çevirisinin doğasından kaynaklanan farklılıkların ve/veya kısıtlamaların rolü olup olmayabileceği ve küfür çevirisinin örtmece içermesinin çevirmen üzerinde kısıtlayıcı veya özgürleştirici bir etkisinin olup olmadığı da örnekler üzerinden tartışılacaktır.

\section{LITERATÜR TARAMASI}

\subsection{Küfür ve çevirisi}

Küfür, Tony McEnery'nin, "nezaketli sohbet olarak nitelendirilebilecek bir iletişimde kullanıldığında dargınlık ve incitme yaratabilecek herhangi bir söz ya da ifade" olarak tanımladığı kaba ve saldırgan dile örnek sayılabilir (2005, s. 1-2). Lars Gunnar Andersson ve Peter Trudgill'in (1990) küfür tanımında ise üç özellik öne çıkmaktadır. Buna göre, küfür, o kültürde tabu ve/veya damgalanmış olarak görülen bir konuya gönderme yapan, birebir yorumlanmaması gereken, güçlü duygu ve düşünceleri ifade etmek için başvurulabilen bir dil kullanımı olarak tanımlanabilir (Gunnar Andersson ve Trudgill, 1990, s. 53). Bu tanımdan yola çıkarak, küfür ile kaba dil kullanımı arasında bir ayrım yapmak gerekmektedir. Küfretme eylemiyle, sarf edilen sözcüğün sözlükteki birincil anlamının ötesine geçerek öfke, kızgınlık, küçümseme gibi güçlü duyguları ifade etmek amaçlanmaktadır (Fernández Dobao, 2006 s. 222). Örneğin, İngilizcede "bok" anlamındaki "shit" sözcüğü birebir temel anlamı kastedilerek kullanıldığında küfür olarak kabul edilmezken, hakaret etmek veya olumsuz bir duyguyu ifade etmek için tepki olarak sarf edildiğinde küfretme sayılacaktır (Soler Pardo, 2013, s. 125). Buna ek olarak, aynı küfür birbirinden çok farklı duyguları ifade etmek için de kullanılabilir. Dolayısıyla, yazılı veya sözlü bir metinde geçen küfrün taşıdığı işlevi saptamak için, küfürlü veya müstehcen sayılabilecek bu ifadenin kullanıldığı bağlamı ve kullanan kişinin amacını anlamak önem arz eder.

Argo ve küfür arasındaki farka bakmak gerekirse argo da küfür gibi, ölçünlü dil kullanımına göre ölçüsüz ve bayağı olarak kabul edilir ve bu nedenle ebeveynler, öğretmenler ve benzeri otorite figürleri tarafından onaylanmayan bir dil kullanımıdır (Lantto, 2014, s. 634). Ferit Devellioğlu'nun tanımına göre argo, “özel diller (langues spéciales) zümresindendir; genel dilin 
sözcüklerine bazı özellikler vermek ve özel sözcükler katmakla meydana gelmiştir" (1980, s. 13). Buna karşılık argo ve küfrün birbirinden ayrıldığı bir nokta, küfürlü ifadelerin çoğunlukla tabu sayılan konularla ilgili olması fakat argonun tabu ifadelerle sinırlı olmamasıdır (Lantto, 2014, s. 641). Diğer bir deyiş̧le, her argo tabu içermeyebilir ve bu anlamda argonun kapsamının daha geniş olduğu söylenebilir. Örneğin "birisiyle dalga geçmek" anlamındaki "maytap geçmek" argo bir ifade iken, erkek cinsel organına kaba bir dil kullanımıyla gönderme yapılarak oluşturulan "ta.ak geçmek" küfür teşkil etmektedir. Bu ayrım özellikle çalışmamız kapsamında, dizinin orijinalinde örtmeceye uğramış bir küfrün Türkçeye hem örtmece hem de küfür göz ardı edilerek argo bir ifadeyle aktarıldı̆̆ı durumlarda yarattığı temsil kayması açısından dikkate değer bir noktayı oluşturmaktadır.

$\mathrm{Bu}$ noktada küfür ile tabu arasındaki ilişkiye bakmak da yerinde olacaktır. Allan ve Burridge, tabuyu "nahoş olan ya da kulağa çirkin gelen ve bu nedenle de sıkça yanlış bir şekilde müstehcen olarak nitelendirilen" ifadeler olarak tanımlamaktadır (2006, s. 242). Küfür aşağılayıcı ve/veya hakaretamiz olan bir ifade iken; tabu, kullanıldığ hoş karşılanmayan herhangi bir sözcük olabilir (Ávila-Cabrera, 2015, s. 38). Bununla birlikte küfür ve tabu sözcükler, sarf edildiğinde seyirci/dinleyici/okur tarafından fark edilmeleri ve söylendiği bağlamdaki, dilsel ideolojiler de dâhil olmak üzere, toplumsal tutum ve değer yargılarıla ilişkili olmaları açısından bir arada kullanılabilmektedir (Bednarek, 2019, s. 1). Dolayısıyla, küfürlü ifadeler, belli bir kültürde tabu olarak kabul edilen konularla ilgili olmaları ve o toplumun değerlerini ve inançlarını yansıtmaları bakımından kültüre özgüdür (Andersson ve Trudgill, 1990, s. 57). Kültüre özgü olma durumu, küfürlerin görsel-işitsel çevirisi üzerine olan literatürde vurgulanan bir noktayı oluşturmaktadır.

Küfürlü ifadelerin görsel-işitsel çeviride aktarılma biçimlerini incelemeyi önemli kılan bir başka nokta, sözü edilen dilsel ögelerin seyirciye bir karakterin kişiliği, ruh hali ve/veya sosyal statüsü konusunda bilgi sunmalarıdır (Ávila-Cabrera, 2015, s. 38). Küfür, kullanıldığı bağlama göre, "hem konuşmanın hem de konuşmacıların ayırt edici özelliklerini anlamakta" önemli bir rol oynayabilir (Fernández Dobao, 2006, sf. 239). Dolayısıyla, görsel-işitsel çeviride küfür ve tabu sözcüklerinin kullanımının bir filmdeki karakterlerin öne çıan özelliklerine ve tematik işlevin yerine getirilmesine net bir şekilde katkı sunduğu dikkate alınmalıdır (Díaz-Cintas ve Remael, 2007, s. 197). Aksi takdirde, çeviri sürecinde küfürlerin silinmesi veya çıkarılması metnin iletişim gücünü olumsuz yönde etkileyebilir ve bunun sonucu olarak seyirciye dolaylı olarak aktarılmak istenen bir mesaj veya birakılmak istenen bir etki kaybolacağı için anlam ve temsil kaybı kaçınılmaz olur (Greenall, 2011, s. 60). Örneğin, iki karakter arasındaki kişilik farkı küfürlü konuşmanın kullanılıp kullanılmaması üzerinden gösterilebilmektedir. Buna ek olarak, küfür kullanımı ekranda karakterler arasındaki çatışmayı gösterme rolü de üstlenebilir (Trupej, 2019, s. 66).

Küfürlü ve kaba sayılabilecek ifadelerin literatürde vurgulanan işlevlerine rağmen, çevirmenlerin yüzyıllar boyunca okurların hassasiyetlerini gözeterek kaynak metindeki rahatsız edici olabilecek unsurlardan kaçındıkları gözlenmiştir. Görsel-işitsel çeviride, özellikle film altyazılarında küfürlü ifadelerden sıklıkla kaçınıldığı tespiti literatürdeki pek çok çalışmada 
vurgulanmaktadır (Chen, 2004; Pujol, 2006; Díaz Cintas ve Remael, 2007; Ávila-Cabrera, 2015). Díaz Cintas, müstehcen ifadelerin seyircide kabul görme derecelerinin ülkeden ülkeye ve hatta aynı ülkedeki farklı sosyal ve etnik gruplar arasında bile farklılık gösterebileceğini belirtmektedir (2001, s. 65). Dolayısıyla, bu farklılıklar küfür çevirisindeki eğilimlerin ülkeler arasında neden ve ne derecede değiştiğinin ve kaçınma veya silme gibi çeviri stratejilerinin daha çok veya daha az hangi bağlamlarda gözlemlendiğinin belirlenmesinde rol oynayabilmektedir.

Yukarıda sözü edilen kaçınma, küfürlü ve tabu sözcüklerin yumuşatılması ya da tamamen çıkarılması şeklinde gerçekleştirilebilir. Ancak, küfürlerin çıkarılması altyazı çevirisinin doğasından kaynaklı teknik kısıtlamalardan ${ }^{1}$ dolayı olabileceği gibi, küfürlerin kalıp içinde kullanıldığı ve birebir çeviri yoluyla aktarılamayacağı durumlardan da kaynaklanabilmektedir. Bu durumlarda, erek dilde benzer bir tona ve anlama sahip ifadeler bulmak veya eğer buna uygun ifadeler yoksa, altyazının başka bir bölümünde bir küfür kullanarak kaynak metindeki etkiyi telafi etmek gerekebilmektedir (Fernández Dobao, 2006, s. 228).

İlgili telafinin yapılmadığı ve çeviri sürecinde küfürlü ifadelerin çıkarılmak suretiyle silindiği bir durumda görsel-işitsel metnin maruz kaldığı değişim başka sonuçları beraberinde getirmektedir. Janko Trupej (2019), çeviride küfür ve argo içeren ifadelerden kaçınılmasının seyircinin bir filmin konusunu, o filmdeki karakter temsilini, karakterler arasındaki ilişkileri algılamasını değiştirebileceğini tespit etmektedir. Örneğin, küfürbaz bir karakter muhataplarına aslında olduğundan daha az agresif ve/veya daha seviyeli biri gibi görünebilir. Dolayısıyla, dizi veya filmde öykünün gidişatı açısından bu temsil kayması özellikle önemli bir sorun teşkil edebilmektedir (Trupej, 2019, s. 65). Birbirinden farklı karakterlerin biraraya geldiği İyi Yer özelinde de küfretmenin karakter temsilinde ne şekilde belirleyici olduğu karakterlerin birbirleri arasındaki iletişimini anlamak ve örtmeceli küfürlerin çevirisini bu açıdan incelemek önemli olacaktır.

Örtmece, çeviri bağlamından bağımsız olarak, küfür ve tabu sözcükleri kullanmaktan kaçınma yollarından biri olarak sayılabilir. Çeviri bağlamında ve özelde de küfür çevirisinde altyazı ve/veya dublaj çevirmeninin izleyebileceği bir strateji olarak örtmecenin kullanılabildiği görülürken, bir görsel-işitsel metin üzerinden örtmeceli küfür çevirisine odaklanılan bir çalışmaya rastlanmamaktadır. Mizah ve küfür çevirisinin dizinin kurmaca dünyasında yer alan bir küfür filtresi yoluyla ve örtmece kullanılarak biraraya geldiği bir görsel-işitsel metin olması bu çalışmada İyi Yer dizisine odaklanmanın nedenini oluşturmaktadır. Dolayısıyla, dizinin İngilizceden Türkçeye çevirisi incelenirken hem küfrün hem de örtmecenin işlevlerinin göz önünde bulundurulması gereği ortaya çıkmaktadır. Bu noktada, İyi Yer'de kullanılan örtmece biçimlerinin ve işlevlerinin tespitinde yol gösterici olması bakımından, örtmece tanımına ve işlevlerine değinilecektir.

\footnotetext{
${ }^{1}$ Altyazı çevirisinde çeviri türünün doğası gereği teknik bazı kısıtlılıklar söz konusudur. Sözgelimi, okuyucunun okuma hızı dikkate alınarak belirlenen süre ve sahnenin değişmesine göre yazının ekranda kalma süresi en önemli zamansal kısıtlılıklarından biridir. Genel altyazı standartlarına uygun olarak ekranda yer alabilecek en fazla karakter sayısı olan uzamsal kısıtlılık bir diğeridir. Buna bir de görüntülerle işitsel düzgünün birbirini tamamlaması biçimindeki senkron sorununu ekleyebiliriz (Oğuz, 2017, s. 275-290).
} 


\section{2. Örtmece ve işlevleri}

Ralph Keyes, örtmeceleri "bizi rahatsı hissettiren sözcük ve ifadeler yerine kullandıklarımız" olarak tanımlamaktadır (2010, s. 42). Allan ve Burridge'in tanımına göre ise, örtmece itibar kaybından kaçınmak için tercih edilmeyen ifadelere alternatif olarak kullanılan ifadelerdir (1991, s. 14). Buna göre, tercih edilmeyen ve örtmeceye uğrayan ifadeler tabu olabileceği gibi, korkutucu veya başka sebeplerden ötürü kişinin iletişimsel niyetini uygun bir şekilde aktaramayacak ölçüde olumsuz anlam çağrıştıran ifadeler de olabilir (a.g.e, s. 14). Örneğin, tabunun çok güçlü olduğu ve/veya konuşanın konu ile duygusal angajmanının olduğu durumlarda, örtmece bir sözün kırıcı ya da incitici olma ihtimalini hafifletme yolu olarak görülebilir (Allan, 2012, s. 6). Bu anlamda, örtmecenin iletişimde bir kaçış stratejisi olarak uygulandığı söylenebilir.

Yaygın örtmece yapma biçimlerinden birisi olan ve İyi Yer'de de görülen örneği ise yeniden modellemedir. Bu yöntem, orijinali ile yerine türetilen terim arasında daha çok ya da daha az bir dereceye kadar fonetik veya ortografik benzerliği koruyan bir örtmece yapma biçimi olarak tanımlanabilir (Allan, 2012, s. 7). Buna göre, yeniden modelleme, nahoş ya da söylenmesi tercih edilmeyen bir sözcüğün anlamsal olarak onunla alakası olmayan ya da tamamen anlamsız sayılabilecek başka bir sözcükle ikame edilmesi şeklinde gerçekleşebilir (Farghal, 1995, s. 375). Bu süreç fonolojik olup bazı durumlarda anlamda bozulmaya neden olabilmektedir (Thawabteh, 2012, s. 152).

Yeniden modellemenin pragmatik nedenlere dayalı olarak yapıldığı söylenebilir (a.g.e., s. 152). Kısaltma ya da fonetik olarak benzer sözcüklerle ikame edilerek yapılan yeniden modelleme ile tabu olarak kabul edilen sözcüklerden kaçınılabilir (Allan, 2012, s. 7). Buna ek olarak, yeniden modellemenin yapılma biçimlerinden bir diğeri harflerin yerlerini değiştirmektir. Buna göre, yeniden modelleme yapılırken sözcüklerde bir tanınmazlık etkisi yaratmak amacı her zaman güdülmeyebilir. İngilizcede "fuck" küfrünün yazılı bir metinde "f!ck" olarak değiştirilmesi veya İyi Yer'de de göreceğimiz gibi "fork" olarak söylenmesi bunun örnekleri olarak verilebilir. Böylece, örtmecenin yapılma nedenine de bağlı olarak, okurun veya seyircinin, yeniden modellenen sözcügün orijinal halini kolayca tahmin etmesi sağlanabilir. Dolayısıyla, örtmece çevirisinin sadece dilsel ve kültürel açıdan değil, aynı zamanda teknik yönden de zorlayıcı yanları vardır (Thawabteh, 2012, s. 146). Küfür çevirisinde olduğu gibi, bir metinde neden örtmece kullanımına başvurulduğu ve bunun altında ne tür bir motivasyon yattığını bilmek yeniden modelleme yoluyla yapılmış örtmecenin ne şekilde çevrileceğinin belirlenmesinde önemli bir rol oynar. Bir sonraki bölümde İyi Yer dizisinde orijinal metindeki küfür filtresinin özellikleri ve örtmece yapma biçimleri tarif edilecek, örtmeceli küfürlerin çevirisinde ne gibi yollar izlendiği ve kaynak metinle karşılaştırıldı̆̆ında Türkçede çeviri yoluyla örtmeceli küfür oluşturmadaki benzerlikler ve farklılıklar tespit edilecektir.

\section{IYYI YER (THE GOOD PLACE) VE KÜFÜR FILTRESİ}

Komedi, drama ve fantezi ögelerini bir araya getiren dizinin konusunu özetlemek gerekirse, Eleanor Shellstrop, Chidi Anagonye, Jason Mendoza ve Tahani Al-Jamil adlı dört fani öldükten 
sonra, kendilerini cennet sandıkları İyi Yer'de bulurlar. Dünyada iyi bir insan oldukları için ödüllendirildiklerini zanneden bu dörtlüyü İyi Yer'de mekânın mimarı Michael karşılar. Mahalleyi tanıttıktan sonra, her birini hayallerine göre tasarlanmış evlerine götürür. İyi Yer' in kendine özgü yönlerinden birisi de her sakinin bir ruh eşinin olmasıdır. Bu nedenle, Michael Eleanor'u ruh eşi olan Chidi ile tanıştırır. Çok geçmeden, Eleanor Chidi'ye bu durumda bir yanlışlık olduğunu, kendisinin bahsedilen Eleanor Shellstrop olmadığını itiraf eder. Ölmeden önce Etik ve Ahlak Felsefesi profesörü olan Chidi için Eleanor'a yardım etmek adına bu yalanı saklamak, savunduğu etik değerler adına bir çelişki ve bu nedenle de işkence hissi veren bir durumdur. Diğer taraftan, ağzı bozuk bir karakter olan Eleanor için işkenceye dönüşen, İyi Yer'in bir başka önemli özelliği, küfür filtresinin olmasıdır. İyi Yer'deki küfür yasağı, söylenmek istenen küfürleri sansürlerken, o küfürle ilgisi olmayan başka bir sözcüğe dönüştürür, diğer bir deyişle örtmeceye uğratır. Daha sonra, Michael'ın aslında Kötü Yer insanlarından biri olduğu, seçilmiş bu dört faniye işkence etmek için İyi Yer'in yalandan bir versiyonu olarak bu yeri kurguladığı ortaya çıkacaktır. Bu kurguyu anlamalarının ardından, bu dört karakterin cehennemi temsil eden Kötü Yer'e gönderilmemek ve gerçek İyi Yer'e gidebilmek için çıktıkları maceraları, bu sırada iyilik ve kötülük üzerine girdikleri felsefi tartışmaları ve bu süreç sonucundaki değişimlerini izleriz.

Dizinin kaynak medyadaki alımlanmasına baktığımızda, dizi üzerine yapılan yorumlarda küfür filtresinin ve örtmeceli küfürlerin dikkat çeken noktalar olduğu görülmektedir. Örneğin, dizinin sansürlenen küfürlerinde başvurulan örtmece kullanımındaki yaratıcılık seyirci üzerindeki mizah etkisi üzerinden tartışılmıştır (Hazen, 2020, para. 16). Benzer şekilde, dizinin oyuncuları ile yapılan bir röportajda senaristlerin örtmece üretmedeki yaratıcılıkları vurgulanmış, onlardan en sevdikleri örtmeceli küfürlerden örnek vermeleri istenmiştir (Bricker, 2016, para. 3). Dizideki örtmeceli küfürlerin literatürde dikkat çektiğini gösteren nadir bir örnek Monika Bedranek'in (2019) dizilerde kullanılan küfür ve tabu ifadeleri sınıflandırdı̆̆ı çalışmasıdır. Bednarek, İyi Yer'deki örtmeceli küfürleri yenilikçi küfür ve tabu ifade kullanımına örnek olarak gösterip “esprili yaratıcılık örnekleri” olarak tarif etmektedir (2019, s. 10). Dizideki bu yaratıcı dil kullanımına çeviri açısından bakıldığında, literatürde de belirtildiği gibi, örtmece çevirisinin değerlendirilmesinde kaynak metinde neden örtmece kullanımına başvurulduğunu bilmek önemli bir rol oynayacaktır. Buna paralel olarak, örtmeceye uğrayan küfürlerin dizideki işlevleri ve karakterlere dair sunduğu veriler, çeviride ilgili verilerin ne ölçüde aktarıldığını, aktarılmaması durumunda ne tür anlam kayıpları veya kaymaları olduğunu tartışma imkânı sunacaktır.

\section{BULGULAR}

İyi Yer'de kaynak metinde sıklıkla kullanılan örtmeceli küfürlerin ve tabu ifadelerin, vücudun çeşitli organlarına gönderme yaptığı veya cinsel faaliyet ve tuvalet alışkanlığ ile alakalı fiziksel bazı süreçler üzerinden bedensel göndermeler içerdiği görülmektedir. Farghal, bir kişinin örtmeceye başvurmasının sıklıkla konuşmacı ile muhatabı arasındaki sosyal ilişki veya ortamın gerektirdiği resmiyet düzeyi gibi bağlamsal faktörlerden kaynaklandığını belirtmektedir (1995, s. 366). Benzer şekilde, İyi Yer dizisindeki örtmece kullanımının bağlamsal oluşu öne çıkmakta ve sadece iyi insanların kabul edildiği ütopik dünyayı temsil eden bu mekânın ayırt edici bir özelliği 
olarak sunulmaktadır. Örneğin, İyi Yer'de bir küfür filtresi uygulandığını öğrendiğimiz ilk bölümün sonlarında geçen sahnede, dizide ağzı bozuk bir karakter olarak tanıtılan Eleanor Shellstrop israrla "fuck up" demeye çalışır ama söylemek istediği küfür örtmeceye uğrar. Kendisinin bahsedilen Eleanor olmadığını ve bir yanlışlık olduğunu Chidi'ye ifade etmeye çalışırken, istemsizce "Somebody royally forked up" demek zorunda kalması üzerine Chidi, İyi Yer sakinlerinin hoşuna gitmediği için küfretmenin orada yasak olduğunu açıklar. Dizide İyi Yer'in dışında geçen, örneğin karakterlerin fani hayatından kesitlerin verildiği veya İyi Yer'in zıddı olarak kurgulanmış Kötü Yer gibi mekânlarda geçen sahnelerde ise, küfür filtresinin yokluğu küfürlerin bilindik haliyle kullanımıyla kendini gösterecektir. Bu alanlar örtmeceli küfürlerin çevirisinin analizine odaklanılan bu çalışmanın kapsamı dışında kalsa da dizinin bütünü üzerinden yapılacak bir değerlendirmede İyi Yer "filtreli alan", bunun dışında kalan yerler ise "filtresiz alan" olarak tanımlanabilir.

Bu anlamda dizide "filtreli alan" diyebileceğimiz İyi Yer'de fiil, isim ve sifat haliyle karşımıza çıkan "fuck" ve versiyonları dizide en çok kullanılan küfürlü ifadedir ve "çatal" anlamına gelen "fork" sözcüğü ile ikame edilerek örtmeceye uğratılmaktadır. Fiil olarak kullanıldığı durumlarda, "up" veya "off" gibi ilgeçler eklenerek oluşturulan deyimsel fiillerin "fork up" ve "fork off" gibi örtmeceli versiyonları kullanılmaktadır. "Fuck" küfrü, İngilizcede isim olarak kullanıldığ durumlarda ise, ünlem ifadelerinde veya soru ve emir cümlelerinde pekiştireç rolünü üstlenebilmektedir. Soru cümlelerinde bunu yapmanın bir yolu, “what" (ne), "who" (kim) ve "where" (nerede) gibi soru sözcüklerinin ardına getirilerek ünlem ifadelerini kuvvetlendirmektir. Dizide sıkça duyulan diğer yolu ise, "fuck" sözcügünün İngilizcede hayal kırıklığı veya şaşkınlık ifade etmek için kullanılan "oh" ünlem ifadesinin ardına getirilerek "oh fuck" biçiminde bu ünlem ifadesini pekiştirmektir. Tablo 1'de, dizide kullanılan küfürlerin orijinal ve örtmeceli versiyonları listelenmiştir. Burada da görülebileceği gibi, dizide kullanılan ve $\dot{I} y i$ Yer'deki küfür filtresine uğrayan sözcükler arasında, aynı küfrün isim, fiil, sıfat gibi farklı türlerine ek olarak, "bullshirt" ve "ashhole" gibi örtmeceli küfür içeren birleşik sözcükler de bulunmaktadir.

Tablo 1. İyi Yer'de kullanılan küfürlü ifadelerin orijinal ve örtmeceli versiyonları

\begin{tabular}{|l|l|}
\hline fuck/fucking/fucker/fucked-up/fuck-nut & fork/forking/forker/forked-up/fork-nut \\
\hline shit/bullshit/shithole/shitballs & shirt/bullshirt/shirthole/shirtballs \\
\hline bitch & bench \\
\hline ass/asshole & ash/ashhole \\
\hline cock/cock-block & cork/cork-blork \\
\hline
\end{tabular}

İyi Yer'deki küfür filtresinin işleyişine baktığımızda üç özellik dikkat çekmektedir. Birincisi, filtrenin karakterlerin sözcük seçimi üzerindeki kısıtlayıcı etkisinin istem dışı bir yönü olduğunun vurgulanmış olmasıdır. Yukarıda verilen örnekte de görülebileceği gibi, Eleanor'un küfredemediğini fark ettiği sahnede ağzından kontrolü dışında küfür yerine başka bir sözcük çıkmasını şaşkınlıkla karşılaması ve küfrü tekrar tekrar söylemeye çalışması dizide mizah etkisini oluşturmaktadır. Dizinin orijinalindeki küfür filtresinin ikinci özelliği, dizi boyunca, her küfrün ve türevinin sansürlenme biçiminde bir tutarlılık izlenmesidir. Örneğin, "fuck" sözcüğünün “fork" ile 
ikame edilmesi gibi, ondan türetilen "fucked-up" ve "fuck-nut" gibi küfürler de "forked-up" ve "fork-nut" şeklinde örtmeceye uğratılmaktadır. Küfür filtresinin üçüncü özelliği, örtmecenin o küfre fonetik olarak benzeyen ama küfür ile anlamsal bir yakınlığı olmayan bir sözcükle değiştirilerek yapılmasıdır. Bununla bağlantılı olarak, küfrün örtmeceli versiyonunu oluşturan bu sözcüğün İngilizcede anlam ifade eden ve gündelik hayatta sıkça kullanılan bir nesneye tekabül etmesi dikkat çekmektedir.

Örnek vermek gerekirse, Tablo 1'de de görülebileceği gibi, "bitch" İngilizcede "sıra" manasına gelen "bench" ile, "ass" ise "kül" manasına gelen "ash" sözcügü ile ikame edilmektedir. Dolayısıyla, dizinin orijinalinde küfürlerin örtmeceye uğratılmasında, sözcüğün kısaltılması, harflerinin değiştirilmesi veya karakterin sesinin duyulmaması gibi yollar izlenmemektedir. Dizinin yaratıcıları, sansürlenen küfürde bir tanınmazlık yaratmaktansa, ilgili sözcüğü çağrıştıran fakat küfürle alakası olmayan objelerle örtmeceye başvurmaktadır ve böylece mizah etkisi yaratılmaktadır. Bu anlamda, küfürlerin orijinali ile yerine kullanılan sözcük arasında fonetik benzerliğin korunmasına dikkat edilmesi açısından İyi Yer'deki örtmecelerin yeniden modelleme yoluyla yapıldı $\breve{g}$ tespit edilebilmektedir.

Dizideki örtmeceli küfürlerin altyazı ve dublaj çevirileri incelendiğinde, küfür filtresinin İngilizce orijinalde öne çıkan bu özelliklerinin Türkçeye aktarılmasında farklılıklar görülmektedir. Buna göre, aynı örtmeceli küfür hem altyazıda hem de dublajda farklı cümlelerde farklı şekillerde çevrilebilmekte ve İngilizcede listelendiği gibi örtmece kullanımında bir tutarlılık gözetilmemektedir. Örneğin, İngilizcede "fork up" olarak sansürlenen "fuck up" küfürlü ifadesi Türkçeye "saçmak" veya "mıçmak" olarak çevrilebilmektedir. Bir başka örnekte ise aynı küfrü içeren farklı bir deyimsel ifade olan "fork off" "sirktir" veya "söktür" olarak çevrilmektedir. Tartışma bölümünde de belirtileceği gibi, bu durum küfürlerin kalıplı yapılar içerisinde kullanılmasına ve diller arasındaki yapısal farklara bağlanabilecekse de Tablo 3'te verilen farklı örnekler üzerinden görülebileceği gibi, çevirideki söz konusu tutarsızlık bu tür ifadelerin dışında tek başına kullanılan "bench" veya "ashhole" gibi örtmeceli küfürlerin çevirisinde de yaygın bir şekilde görülmektedir.

Buna ek olarak, verilen örneklerde görüldüğü gibi, Türkçe çeviride küfürler örtmeceye uğratılırken İngilizce orijinalinden farklı olarak, Türkçede anlam ifade eden ve bir objeyi temsil eden bir sözcük ile ikame edilmesi gözetilmeden, küfürdeki harf veya harfler değiştirilerek filtrelenmektedir. Bu anlamda, her ne kadar İngilizcedeki filtreleme özelliklerini taşımasa da Türkçe çevirilerdeki küfür örtmecelerinin de Allan'ın (2012) belirttiği "yeniden modelleme" biçiminde yapıldığı tespit edilebilmektedir. Dizinin üç sezonu üzerine filtreli alanı yani küfür filtresinin kullanıldığı İyi Yer'deki diyalogları baz alarak yaptığımız inceleme sonucu çıkarılan listeye göre, dizinin çevirisinde tespit edilen küfür filtreleme(me) türleri dört gruba ayrılabilir. Tablo 2'de de görülebileceği gibi, ilk iki filtreleme türü olan F1 ve F2 arasındaki fark dizinin orijinalinde var olan örtmece kullanımının çeviride aktarılması ve aktarılmaması noktasına dayanmaktadır. Buna karşılık, ilk iki türden farklı olarak F3'te ve F4'te dizinin orijinalinde örtmeceli küfür kullanımı yoktur fakat çeviride bu nokta göz ardı edilerek küfür veya örtmeceli küfür eklemesi yapıldığı durumlar gözlenmektedir. Bu nedenle, Tablo 2'de çeviride küfür 
filtreleme ve filtrelememe biçimleri bir arada verilmekte ve bunu yansıtacak şekilde tablo "küfür filtreleme(me) türleri" olarak adlandırılmaktadır.

Tablo 2. İyi Yer'in çevirisinde tespit edilen küfür filtreleme(me) türleri

\begin{tabular}{|l|l|l|}
\hline Filtreleme türü & İngilizce orijinal & Türkçe çevirisi \\
\hline F1 & Örtmeceli küfür var & Örtmeceli küfür var \\
\hline F2 & Örtmeceli küfür var & Örtmeceli küfür yok \\
\hline F3 & Örtmeceli küfür yok & Örtmeceli küfür var \\
\hline F4 & Örtmeceli küfür yok & Küfür var \\
\hline
\end{tabular}

Tablo 2'de listelenen filtreleme türlerine baktığımızda, F1 olarak adlandırdığımız birinci filtreleme türü İyi Yer'de filtrelenen İngilizce küfrün Türkçeye, yukarıda belirtildiği gibi anlam ifade edip etmemesi gözetilmeden de olsa, örtmeceye uğratılarak aktarılan örnekleri kapsamaktadır. Bu kategoriye giren örtmeceli küfürler ve çevirileri Tablo 3'te listelenmiştir. Bu listede de görüldüğü gibi, Türkçe çevirideki örtmeceli küfürlerde yeniden modelleme yapılırken bazı durumlarda sadece tek bir harfi değiştirilerek ("mıçmak", "sürpük", "göp”), bazı durumlarda ise bir harf eklenerek ("sırçayım", "pirç", "oronspu") örtmece yapılmaktadır. Bu örneklerde, Türkçe küfürlerin örtmeceli versiyonlarının İngilizcedeki mukabillerinden farklı olarak, anlam ifade etmediği görülebilmektedir. Buna ek olarak, harf değiştirme yoluyla yeniden modellenen bazı küfürlerin örtmeceli versiyonları, "sökmek", "saçmak", "silkmek" örneklerindeki gibi, Türkçede anlam ifade eden sözcüklerden de oluşabilmektedir.

Tablo 3. İyi Yer'deki İngilizce örtmeceli küfürler ve Türkçe çevirileri (F1)

\begin{tabular}{|l|l|}
\hline fork (with/up/off) & $\begin{array}{l}\text { silkmek/ sirkmek/ saçmak/ sökmek/ mıçmak/ sirktirmek/ söktürmek/ silki } \\
\text { tutmak/ silkmeye kalkmak/ silktirip gitmek/ sirktirmek gitmek/ söktürmek } \\
\text { gitmek }\end{array}$ \\
\hline motherforker & pirç kurusu \\
\hline bench & sürpük/ silkik/ oronspu çocuğu \\
\hline ashhole & mok gibi/göpün teki/ pirç kurusu/gözveren \\
\hline shirt/ shirthole/ bullshirt & maçmalı//bottan/ saçtım/ sırçayım/ börk \\
\hline
\end{tabular}

Ayrıca İngilizce örtmeceli küfürler ve çevirileri listelendiğinde, aynı örtmeceli küfrün farklı şekillerde çevrildiği görülmektedir. Örneğin, İyi Yer denilen mekânın fikir babası ve mimarı olan Michael'in Kötü Yer insanlarını kovduğu sahnede söylediği "Get the fork out of my neighborhood" cümlesi "Hepiniz diktirin gidin mahallemden" olarak çevrilmişken, bir başka bölümde Chidi'nin ağzından çıkan aynı "Get the fork out" cümlesi "Silktir git" olarak farklı bir örtmeceyle verilmiştir. Buna ek olarak, "fucking" küfrünün pekiştirme zarfı olarak "şaka yapmak", "dalga geçmek" anlamındaki "to be kidding" fiilinin önünde kullanıldığ 1 ve "forking kidding" olarak filtrelenen ifade Türkçeye her seferinde farklı şekillerde ("Ha diktir", "Ebesinin damı", "Paşak geçiyor" ve "Taşlak geçiyor" gibi) çevrilmiştir. Bu açıdan bakıldı̆̆ında, kaynak metindeki örtmeceli küfürlerin kullanılmasında gözetilen tutarlılığın çeviride muhafaza edilmediği tespiti yapılabilmektedir.

$\mathrm{Bu}$ örneklere ek olarak, F1 kategorisinde değerlendirebileceğimiz bir diğer grup ise çoklu küfür örtmeceleri ve çevirileridir. Yukarıda verdiğimiz örtmeceli küfürlerden farklı olarak, çoklu 
küfür örtmeceleri, kaynak metinde birden fazla küfür örtmecesinin bir arada görüldüğü, "holy forking shirt" veya "forking forked" gibi ifadelerdir. Tablo 4'de ikinci ve üçüncü sütunlarda sırasıyla çoklu küfür örtmecelerinin altyazı ve dublaj çevirileri verilmiş olup parantez içindeki sayılar Türkçeye aktarılan örtmeceli küfür sayısını ifade etmektedir. Tabloda da görülebileceği gibi, çevirilerde örtmeceli küfürlerin erek metne eksiksiz bir şekilde aktarılmadı̆̆ı tek bir örnek bile yoktur. Tabloda parantez içinde " 0 " sayısının görüldüğü "O buna inanamıyorum" gibi örneklerin, örtmecenin hiç aktarılmaması bakımından F2 türüne dâhil edilmesi gerektiği ayrıca söylenebilir. Bunlar arasında, çoklu örtmeceli bir küfrün "şeyini şey ettiğimin şeyi" olarak çevrilmiş olması küfür söylemekten kaçınma iması taşıması bakımından örtmece olarak değerlendirilebilecekse de örtmeceyi Türkçeye aktarmakla ilgili bir yaratım süreci içermemesi açısından Tablo 3’teki F1 türü altındaki diğer örneklere uymadığı da görülmektedir.

Tablo 4. İyi Yer'deki çoklu küfür örtmeceleri ve çevirileri

\begin{tabular}{|c|c|c|}
\hline Örtmeceli küfür (İng) & Altyazı çevirisi (Tr) & Dublaj çevirisi (Tr) \\
\hline "Holy forking shirt" (2) & "Ha silktir" (1) & “O buna inanamiyorum." (0) \\
\hline $\begin{array}{l}\text { "Holy mother-forking shirtballs" } \\
\text { (2) }\end{array}$ & $\begin{array}{l}\text { "Hay şeyini şey ettiğimin } \\
\text { şeyi!" (0) }\end{array}$ & "Yok artık ha söktür oradan be!" (1) \\
\hline "Holy forking shirtballs" (2) & “Vay damına koyayım" (1) & “Hay anasını sirkeyim." (1) \\
\hline "Holy forking fork!" (2) & "Vay ebesinin damı" (1) & "O yok artık daha neler" (0) \\
\hline $\begin{array}{l}\text { "royally forking forked" } \\
\text { (2) }\end{array}$ & $\begin{array}{l}\text { "dirgenle krallar gibi } \\
\text { deliniriz" }(0)\end{array}$ & "fena kapak olabilir" (0) \\
\hline
\end{tabular}

F2 olarak adlandırdığımız ikinci kategori, İngilizce orijinal metinde örtmeceli küfrün yer aldığ1 ancak Türkçe çeviride örtmeceli küfrün olmadığ1 ve hem küfrün hem de örtmecenin yok sayıldığı örneklerden oluşmaktadır. Dizinin ilk üç sezonunu incelediğimizde orijinal metinde küfür ve örtmece olduğu halde, erek dilde küfrün yok sayıldığı bölümlerin oranının oldukça fazla olduğu görülmektedir. Kaynak metinde 80 örtmeceli küfür yer alırken bu sayı altyazıda 37, dublajda ise 33'tür. Çeviri örneklerinden bazıları Tablo 5'te listelenmiştir. Bu tablodaki örneklerde görüldüğü üzere İngilizce orijinal metinde yer alan örtmeceli küfürler, çeşitli sahnelerde bağlama göre erek dilde örtmecesiz ve yeniden modelleme yapılmaksızın Türkçeye çevrilmiştir.

Tablo 5. İyi Yer'deki örtmeceli küfürlerin örtmecesiz Türkçe çevirileri (F2)

\begin{tabular}{|l|l|}
\hline fork & hadi oradan/vay be \\
\hline fork with & maytap geçmek/ dalga geçmek/kafa bulmak \\
\hline fork up & kafayı buldurmak/ adamın canına okumak \\
\hline forked-up & rezil/ berbat \\
\hline bull-shirt & saçmalık / deli saçması \\
\hline bench & pislik/ şıllık \\
\hline motherforker & Yok artık! / Hadi oradan be! \\
\hline messy bench & Şırfıntının teki/ sinsi bir şeytan \\
\hline
\end{tabular}

F2 kategorisindeki küfürler, tespitlerimize göre Türkçeye iki farklı yöntemle çevrilmiştir. İlk dikkati çeken aktarım biçiminde, küfürlerin çevirisinde Türkçede günlük dil kullanımında yer 
alan, sıradan, küfür sayılamayacak ifadeler seçilmiştir. Sözgelimi, "fork” örtmeceli küfrü, "hadi oradan" ya da "vay be" biçiminde dizinin orijinalindeki etkisini hissettirmeyecek biçimde küfür niteliği olmayan ifadelerle verilmiştir. Diğer aktarım biçiminde ise küfürlerin çevirisinde örtmeceye uğratılmadan kaba konuşma diline ait ifadeler tercih edilmiştir. Buna örnek olarak "bitch" sözcügünün örtmeceli versiyonu olan "bench" için "şıllık" ve "şırfıntı" gibi kaba konuşmada kullanılan sözcüklerin kullanımını verebiliriz.

Spesifik olarak, Eleanor'un Tahani'ye "Girl, you're a messy bench" (S2B7; ZK 05:02) dediği cümlede kullandığı örtmeceli küfrün, altyazıya "Kızım sen şırfıntının tekisin” biçiminde, TDK'ya göre "seviyesi düşük, bayağı" olarak tanımlanan, kaba konuşma diline ait "şırfıntı" sözcüğü ile örtmeceye uğramadan çevrildiği görülmektedir. Söz konusu küfür, dublaja ise "Ah güzelim drama seven sinsi bir şeytansın" biçiminde sıradan, küfür sayılamayacak günlük bir ifade ile aktarılmıştır. Burada dikkat çeken nokta, "bench" küfrünün çevirisinde kullanılan çeşitli ifadelerin erek dilde örtmeceye uğrama biçiminde kendini gösteren farklılık, diğer bir deyişle tutarsızlıktır. Daha önce sözü edilen tutarsızlık, "bench" örneğinde de kendini göstermektedir ve çevirilerde bu sözcüğe karşılık "şıllık", "pislik", "şırfıntı" gibi farklı kullanımlara rastlanmaktadır. Bu ifadeler Türkçede örtmeceye uğratılmadan kullanılmıştır ancak "şıllık" ve "şırfıntı" gibi sözcüklerle eşanlamlı sayılabilecek "sürtük" sözcüğü F1 kategorisinde gördüğümüz üzere "sürpük" biçiminde örtmeceye uğratılarak çevrilmiştir. "Sürpük" dışında söz konusu diğer örneklerin küfürden ziyade argo ve kaba konuşma diline ait ifadeler olduğu dikkat çekmektedir.

F2 kategorisinde listelenen küfürler, dizinin orijinalinde çeşitli sözcük kombinasyonlarıyla deyim/fiil, ad, sıfat ve zarf biçiminde karşımıza çıkmaktadır. Sözgelimi, "fork off", "fork with", "fork me" gibi örtmeceli küfürler, "hadi oradan be", "maytap/dalga geçiyorsun" veya "hay lanet bana" olarak örtmeceye uğramadan çevrilmiştir. Sıfat ve zarf olarak kullanılan örneklerde ise dikkat çeken, söz konusu ifadelerde küfürlerin pekiştireç işlevini görmesidir. "Fork"un "-ing" son ekini alarak sıfat olarak kullanıldığ 1 "forking bird" ifadesinin "kuş" biçiminde veya zarf olarak kullanıldığ 1 "I forking knew it" cümlesinin "Biliyordum/ Biliyordum işte" biçiminde çevrilirken küfürlerin göz ardı edilmesi, tartışma bölümünde de irdeleneceği üzere, diller arası yapısal farklılıktan kaynaklanabilir.

F2 kategorisindeki örneklerin genelinde sözü edilen iki yöntemin yanı sıra çevirmenin ekleme yoluyla metne müdahale ettiği örnekler de söz konusudur. "Fork" sözcügünün yine pekiştireç görevinde kullanıldığı örnekte, Eleanor'un partide dikkat dağıtmak için kullandığı “We need a distraction. Right the fork now" (S1B4; ZK 15:16) ifadesi, altyazıda "Şu anda dikkat dağıtıcı bir şeye ihtiyacımız var" biçiminde iki cümlenin birleştirilmesiyle ve örtmeceye uğratılmadan verilmişken, dublajda ekleme yapılarak "Hemen dikkat dağıtmalıyız. Yoksa işimiz bitti” biçiminde aktarılmıştır. Çevirideki ilk cümle orijinali ile örtüşürken "hemen şu anda" anlamındaki "right the fork now" bölümünden örtmeceli küfür çıkarılmış, ifade "yoksa işimiz bitti" biçiminde bir telafi cümlesiyle tamamlanmıştır. Sözü edilen telafi, tartışma bölümünde belirtileceği üzere, dublajın teknik özelliklerinin gereği olduğunu düşündürmektedir.

Bunların yanı sıra, F2 kategorisinde değerlendirilen bir başka grup, örtmecenin oluşturulmasında istem dışılık etkisinin göz ardı edildiği izlenimi veren ve bu anlamda harf değişikliğine uğratılarak yeniden modellenen "sürpük", "diktir", "hötler", "silk" gibi örtmeceli küfür çevirilerinden farklılık gösteren örneklerdir. İyi Yer'de bir üst sansür olarak işleyen küfür 
filtresinin altında yatan istem dişılık noktası dizinin mizah etkisi yaratmasına bağlandığı için bu tür örneklerde mizah etkisinin kaynağının belirsizliğe uğradığı iddia edilebilir. Buna karşılık, bu istem dışılık etkisinin göz ardı edildiği ve küfür kullanımının zorunlu bir örtmeceden ziyade bir kaçınma şeklinde gerçekleştiği izlenimi veren örneklerde örtmeceli küfürler, onları çağrıştıran başka sözcüklerle ikame edilmiştir. Sözgelimi, Eleanor'un ağzından küfür filtresiyle çıkan "Motherforkers" (S3B12; ZK 06:58) ifadesi dublajda "Anasını sevdiklerim" olarak aktarılmaktadır. Bir başka örnek, Eleanor'un Chidi'ye üzerinde "Fork off, Eleanor" (S1B5; ZK 20:05) yazan bir kart gösterdiği sahnedir. Kart üzerinde yazılı olarak yer alan küfür, dublajda görüntü dışı olarak hem Chidi'nin sesinden hem de ekranda yazı olarak "çektir git" biçiminde çevrilmiştir. "Çektir git" ve "Anasını sevdiklerim" ifadeleri her ne kadar "s.ktir git" ve "anasını s.ktiklerim" küfürlerini çağrıştırsa da F1 kategorisindeki örneklerden farklı olarak burada karakter tarafından bilinçli ve istemli bir biçimde küfretmekten kaçınıldığı izlenimi oluşmakta ve böylece üst müdahale ile karakterin kontrolsüz bırakılması ve bunun orijinalde yarattığı komik etki tam olarak aktarılamamaktadır.

F3 kategorisinde İngilizce orijinal metinde sözcük oyunlarıyla oluşturulmuş, küfür teşkil etmeyen ve bu nedenle örtmeceye maruz kalmayan argo ifadelerin çevirisi yer almaktadır. Tablo 6'da verilen örneğin geçtiği sahne Jason adlı karakterin İyi Yer'de Budist bir keşiş olarak bilinmesi ancak normalde keşişlikle ilgisi olmayan, hatta kirli işlere bulaşmış bir DJ olması ve bunu saklamaya çalışması ile ilgilidir. İyi Yer'e nasıl geldiğini anlamaya çalışan ve tıpkı Eleanor gibi bulunduğu yer ile ilgili bir yanlışlık olduğunu düşünen Jason Eleanor'a durumunu açıkladıktan sonra ikisi birlikte bir plan yapmaya karar verirler. Eleanor Jason'a gizli bir yere ihtiyaçları olduğunu söylediğinde Jason ona "Let me show you my bud-hole" diyerek evin arkasındaki gizli odasından söz eder. Konuşma dilinde bunu "butthole” olarak anlayan Eleanor şaşırınca Jason'un onu odaya götürmesiyle kullandığı sözcüğün "butt” olmadığı, "buddy” sözcüğünün kısaltmasını kullandığ1 anlaşılır. Bu sahnedeki "bud-hole" sözcügü Türkçeye "arka deliği" olarak çevrilmiştir. Türkçedeki "arka" sözcügüu, hem "arkadaş”ın kısa hâlidir, hem de "arka" anlamıyla "butt" sözcüğünü karşılamaktadır. Dolayısıyla, buradaki çeviride, çevirmenin yaratıcılığı sayesinde hem anlamin hem de sözcük oyununun verildiği söylenebilmektedir.

Tablo 6. İyi Yer'de sözcük oyununun Türkçede örtmeceli küfür çevirisi (F3)

\begin{tabular}{|c|c|c|c|}
\hline $\begin{array}{l}\text { Zaman } \\
\text { Kodu }\end{array}$ & İngilizce Orijinal Metin & Altyazı & Dublaj \\
\hline 04:02 (S1B4) & $\begin{array}{l}\text { Jason: Let me show you my } \\
\text { bud-hole. } \\
\text { Eleanor: What? } \\
\text { Jason: This is my bud-hole. } \\
\text { It's just like a hole where my } \\
\text { friends and my buds can } \\
\text { hang out. } \\
\text { Eleanor: Oh! bud-hole! Okay, } \\
\text { now I get it. }\end{array}$ & $\begin{array}{l}\text { Jason: Sana arka deliğimi } \\
\text { göstereyim. } \\
\text { Eleanor: Ne? } \\
\text { Jason: Burası benim arka } \\
\text { deliğim. Ben ve dostlarımın } \\
\text { takılabileceği bir delik. } \\
\text { Eleanor: Ah, dost deliği! } \\
\text { Tamam şimdi anladım. }\end{array}$ & $\begin{array}{l}\text { Jason: Sana arka deliğimi } \\
\text { göstereyim } \\
\text { Eleanor: Ne? } \\
\text { Jason: Burası benim arka } \\
\text { deliğim. Arkadaşlarımla } \\
\text { takılabileceğim küçük bir delik } \\
\text { işte. (G) } \\
\text { Eleanor: Oo, arkadaş deliği! } \\
\text { Tamam şimdi anladım. (G) }\end{array}$ \\
\hline 10:29 (S1B4) & Chidi: Oh, bud-hole & Oo, dost deliği. Tamam. & Oo, şimdi saçtık. (G) \\
\hline
\end{tabular}


Bu kategoriye girebilecek dikkat çekici bir diğer örnek, Chidi'nin aynı sözcüğü kullandığı bir başka sahnede geçmektedir. Bu sahnede, söz konusu oday1 gösterdiklerinde Chidi'nin “Oh, bud-hole" biçimindeki tepkisi, Türkçeye örtmeceli bir kullanımla "şimdi saçtık" olarak çevrilmiştir. Burada, hem kaynak metin bağlamından sapma gösteren hem de birkaç sahne öncesiyle tutarlılık göstermeyen bir çeviri söz konusudur. Ancak söz konusu tutarsızlıkta altyazı ve dublaj çevirisi arasında bir ayrım yapmak yerinde olacaktır. Her iki sahnedeki altyazı çevirisi birbiri ile tutarlılık gösterirken, dublaj çevirisinde örtmece kullanımı tercih edilmiştir. Söz konusu sahnede dublaj çevirmeninin Chidi'nin şaşkınlığını ve endişesini ifade etmek adına mizah etkisini kaynak metinde olmayan böyle bir örtmeceli küfür kullanarak yaratması, altyazı çevirisinden farklı olarak seyircinin kaynak metne erişiminin olmaması faktörüne de bağlanabilir.

F4 olarak adlandırdığımız son kategori, kaynak metinde örtmeceli küfrün yer almadığı, ancak erek metinde küfür kullanımının görüldüğü az sayıda örnekten oluşmaktadır. Tablo 7'de görüldüğü üzere, İngilizce ifadeler, Türkçeye kimi zaman küfür ile kimi zaman da deyimsel kaba sözcükler ve argo ifadeler ile aktarılmıştır. Bu örneklerden ilki Chidi'nin Eleanor'a kızdığı ve onu işlerin ters gitmesinden sorumlu tuttuğu sahnedir. Chidi, İyi Yer'deki sistemi işleyen bir saate, Eleanor'u ise saatin dişlilerine zarar veren bir nesneye benzeterek sistemi bozan, her şeyi mahveden biri olarak betimler. Chidi'nin Eleanor'a sarf ettiği "Actually, you're a hammer, just smashing the gears into dust" cümlesinde "herhangi bir şeyi berbat etmek/mahvetmek" anlamında kullanılan "to smash" ifadesinin altyazıya "içine etmek" olarak argo bir deyimle verildiği görülmektedir. Chidi'nin küfür etmekten imtina eden bir karakter olduğu düşünüldüğünde, örtmeceli küfrün yer almadığı kaynak metinden farklı olarak Türkçe çeviride bir argo ifade tercih edilmesinin Chidi'nin temsilinde bir kaymaya neden olacağı iddia edilebilir.

Tablo 7. İyi Yer'de örtmeceli küfür olmayan bölümlerin küfürlü/argolu çevirileri (F4)

\begin{tabular}{|c|c|c|c|}
\hline Zaman Kodu & İngilizce Metin & Türkçe Altyazı & Türkçe Dublaj \\
\hline 20:48 (S1B1) & $\begin{array}{l}\text { Chidi: Actually, you're a } \\
\text { hammer, just smashing the } \\
\text { gears into dust. }\end{array}$ & $\begin{array}{l}\text { Hatta aslında sen } \\
\text { çekiçsin. Dişlilerin içine } \\
\text { ediyorsun. }\end{array}$ & $\begin{array}{l}\text { Sen dişlileri tıkayan bir engelsin. } \\
\text { Aslında sen dişlileri ezip kıran } \\
\text { koca bir çekiç sayılırsın. }(G)\end{array}$ \\
\hline 07:35 (S1B9) & $\begin{array}{l}\text { Trevor: Ah man, this is } \\
\text { gonna make a primo dump } \\
\text { later on" }\end{array}$ & $\begin{array}{l}\text { Bu yemek çok fena } \\
\text { siçtıracak. }\end{array}$ & $\begin{array}{l}\text { Vay canına! Sonrasında } \\
\text { tuvalette harika çıkacak bu. (G) }\end{array}$ \\
\hline 09:42 (S1B12) & $\begin{array}{l}\text { Michael: I know this entire } \\
\text { neighborhood is.... What's } \\
\text { the human expression? Uh, } \\
\text { yes smokin' hot turd. }\end{array}$ & $\begin{array}{l}\text { Tüm mahallenin de... } \\
\text { Nasıl diyordu insanlar? } \\
\text { Boku çıkmış. }\end{array}$ & $\begin{array}{l}\text { Ve bu tüm mahallenin de... bi } \\
\text { şey olduğunu da... Siz insanlar } \\
\text { nasıl dersiniz? Üstünden duman } \\
\text { çıkan tezek yığını. (G) }\end{array}$ \\
\hline 09:25 (S2B7) & $\begin{array}{l}\text { Michael: The ceremony } \\
\text { will be private, but we } \\
\text { think it would be totally } \\
\text { dope... if you biznatches } \\
\text { (biznitch) came and got } \\
\text { turnt up with us afterward. }\end{array}$ & $\begin{array}{l}\text { Aile arasında bir tören } \\
\text { olacak ama siz şıllıklar } \\
\text { gelip sonrasında bizimle } \\
\text { dağıtırsanız çok kıyak } \\
\text { olur. }\end{array}$ & $\begin{array}{l}\text { Özel bir tören olacak ama siz } \\
\text { haytalar bizimle partilerse çok } \\
\text { kiyak olur. }(\mathrm{G})\end{array}$ \\
\hline $21: 22$ (S3B8) & $\begin{array}{l}\text { Michael: We are all } \\
\text { screwed, 'cause a bunch }\end{array}$ & $\begin{array}{l}\text { Hepimiz sıçtık çünkü } \\
\text { birkaç iblis daha geldi }\end{array}$ & $\begin{array}{l}\text { İşimiz bitti. Bir sürü iblis geri } \\
\text { geldi. (GD) }\end{array}$ \\
\hline
\end{tabular}




\begin{tabular}{|l|l|l|l|}
\hline & $\begin{array}{l}\text { more demons just showed } \\
\text { up. }\end{array}$ & & \\
\hline 06:08 (S2B4) & $\begin{array}{l}\text { Chidi: He'll be a lifeless } \\
\text { Shell of misery forever and } \\
\text { we're all doomed. }\end{array}$ & $\begin{array}{l}\text { Sonsuza dek hayatta } \\
\text { kalacak ve hepimiz boku } \\
\text { yiyeceğiz. }\end{array}$ & $\begin{array}{l}\text { O zaman sonsuza dek boşlukta } \\
\text { sürüklenecek ve hepimizin işi } \\
\text { bitecek. (G) }\end{array}$ \\
\hline 01:02 (S1B10) & $\begin{array}{l}\text { Jason: Oh, Ariana we are } \\
\text { really in it now. }\end{array}$ & Ariana şimdi boka battık. & $\begin{array}{l}\text { Oh, Ariana başımız büyük } \\
\text { belada. }\end{array}$ \\
\hline
\end{tabular}

Benzer biçimde Trevor adlı karakterin kullandığ "make a primo dump" ifadesinde "dump" sözcüğünün Türkçeye "sıçtıracak" olarak çevrilmesi, Michael'ın sarf ettiği "smokin' hot turd" ifadesinin "boku çıkmış" biçiminde ve "We all are screwed" cümlesinin ise "sıçtık" olarak sansürsüz ve örtmecesiz şekilde çevirisi, dizinin orijinalindeki argo/küfür dengesiyle örtüşmeyen ve İyi Yer'deki küfür filtresinin varlığını göz ardı eden örnekler olarak sayılabilir. F4 kategorisinde son olarak Jason adlı karakterin kullandığ1 "biznatches” (biznitch) sözcüğünün çevirisi, küfür ve argo kullanımı açısından söz edilmesi gereken bir örnektir. "Biznatch" sözcüğü, sokak diline hâkim olan, hatta sözcük oyunlarıyla kendine özgü argo ifadeler oluşturan Jason'un yine "biznitch" sözcügünden türettiği bir ifadedir. Bu sözcüğün İngilizce argo sözlüklerindeki tanımlarına bakıldığında "bitch" sözcüğünün farklı bir kullanım biçimi olduğu ve argoda "kanka" anlamına geldiği görülmektedir, ancak "ş1llık" biçimindeki çevirisiyle örtmeceli küfür veya küfür kullanımı olmayan bir metnin çevirisinde argo tercih edilmesi dizideki küfür/argo dengesinin gözetilmeyebildiğini gösteren farklı bir örnek olarak göze çarpmaktadır.

\section{TARTIŞMA}

İyi Yer'in kurmaca dünyasında küfür kullanımının hem karakterlerin temsili ve hem de birden fazla mekânda geçen dizide olayların geçtiği yerin anlaşılmasını belirlemesi açısından önem arz ettiği görülmüştür. Literatürde vurgulandığı gibi (Fernández Dobao 2006; Ávila-Cabrera 2015), karakterlerin kullandığı dil ve küfürlü konuşup konuşmaması karakterlerin ayırt edici özelliklerine dair veri sunarken aynı zamanda iyi/kötü, doğru/yanlış antitezinin işlendiği bu dizide sözünü ettiğimiz karşıtlıklar örüntüsünü izleyicinin algılayabilmesine hizmet etmektedir. Özellikle ana karakterlerden Eleanor'un küfretmeyi seven ağzı bozuk biri olarak resmedilmesi, temsil noktasında anlatıyı oluşturan en belirleyici kodlardan biridir. Diğer taraftan, Eleanor'un zıddı olarak resmedilen Chidi'nin ahlak profesörü olması, etik konusunda özel bir hassasiyeti olması, küfür etmemesi ve buna benzer şekilde Michael'in İyi Yer'in mimarı olarak üstlendiği yönetici görevinin getirdiği sorumlulukla küfre karşı mesafesi de dizinin belirleyici kodlarındandır.

Buna paralel olarak, örtmeceli küfürlerin erek metinde yeniden modelleme yoluyla aktarıldığı ve F1 kategorisinde değerlendirdiğimiz örnekler içerisinde küfürlü örtmecenin kaynak metindeki işlevinden dolayı çeviride silme veya çıkarma yoluyla göz ardı edilemeyeceği bazı durumlar dikkat çekmektedir. Bu örnekler, Bednarek'in (2019) üstdilbilimsel yorum ("metalinguistic comment") olarak tanımladığı, dizinin kurmaca anlatı dünyasında karakterlerin küfür filtresine doğrudan gönderme yaptığı cümlelerde geçmektedir. Karakterlerin küfür edemediklerini fark ettikleri veya küfür edip edemediğini kontrol edip buna göre nerede olduklarını anlamaya çalıştıkları sahnelerde örtmeceli küfür kullanımına farklı bir işlev yüklendiği 
söylenebilir. Örtmeceli küfürler ağırlıklı olarak karakter temsiline dair bir veri sunarken, üstdilbilimsel yorum niteliği taşıyan örtmeceler karakterlerin İyi Yer'i kodlayan küfür filtresine atıfta bulunma ve filtreyi kendi amaçlarına göre kullanma suretiyle bu görsel-işitsel metindeki dilsel yaratıcılık ve mizah etkisi arasındaki bağlantının öne çıkmasına imkân vermektedir. Dolayısıyla, karakterlerin üstdilbilimsel yorumlarının bu bilginin ve etkinin aktarılması adına, bu tür örtmeceli küfürlerin Türkçeye istisnasız bir şekilde çevrilmesini kaçınılmaz kıldı̆̆ı söylenebilir.

Bununla birlikte, kaynak kültürdeki izleyicinin karakterlere dair çıarım yapabilmesine olanak sağlayan küfür kullanımının örtmeceli de olsa çeviri yoluyla aktarılmadığ1 F2 kategorisi temsil kayması ve anlam kaybı gibi birbiriyle ilişkili iki temel sonucu beraberinde getirmektedir. Bu noktada, küfür ve örtmecenin çıkarma yoluyla göz ardı edildiği durumların temsil kaymasına neden olma ihtimali yarattığı birkaç sahneden ve bunların çevirilerinden söz etmek gerekir. Dizinin birinci sezonunda İyi Yer'in mimarı olan ve normalde küfür etmeyen Michael'ın, Kötü Yer'e ait insanları mahalleden kovduğu sahnede sinirlerine hâkim olamayıp küfür ettiği görülür. Michael'ın ağzından çıkan "All of you. Get the fork out of my neighborhood" (S1B9; ZK 20:21) biçimindeki ifadedeki "fork" kullanımı etrafında ve özellikle Eleanor'da şaşkınlık yaratır çünkü ilk defa kendisi dışında bir karakterin ağzından küfürlü ifade çıkmıştır. Erek kültürdeki izleyicinin bu sahnenin önemini anlaması ve Eleanor'un şaşkınlığını doğru bir şekilde yorumlayabilmesi, çeviride bu örtmeceli küfrün aktarılabilmesine bağlı iken cümle altyazıda "Hepiniz diktirin gidin mahallemden" olarak çevrilirken, dublajda "Hepiniz, mahallemden defolun gidin" (G) biçiminde verilmiştir. Dolayısıyla, dublaj çevirisinde örtmecenin göz ardı edilmiş olması İyi Yer-Kötü Yer insanları arasındaki gerilim, Michael'in öfkesi, Eleanor'un şaşkınlığı gibi birden fazla noktanın aktarılması ve anlamlandırılması konusunda erek kitle üzerinde yanıltıcı bir etki yaratmaktadır.

Dizide küfrün hissedilmesi ve karakter temsili açısından yukarıdaki örnekle paralellik gösteren diğer bir örnek, İyi Yer'de olduklarına inandırılan insanların aslında Kötü Yer'de olduklarını anladıkları bir sahnede geçmektedir. Normalde küfür etmeyen Chidi, Michael ile konuşmakta ve bu sırada, Michael Chidi'yi, fani hayatında yaptığı yanlışlar konusunda ikna etmeye çalışmaktadır. Ahlaki doğrulara uygun şekilde yaşamaya ve kararlar almaya çalışırken kararsızlığı ile etrafındaki insanları istemeden yıprattığını fark eden Chidi, kendisiyle ilgili yıllardır fark etmediği bu gerçeği anladığı anda ağzından birden “Oh fork! You are right!" sözleri çıkar (S1B13; ZK 16:58). Hem Chidi'nin uyanışının taşıdığı önem hem de yukarıdaki örnekteki gibi Eleanor dışındaki bir karakterden beklenmeyecek bir küfür kullanımının yarattığı şaşkınlık etkisi göz ardı edilerek, bu örtmece Türkçede altyazıya “Hay lanet!", dublaja ise "Hadi ya!” biçiminde çevrilmiştir. Bu örnekler, Díaz Cintas ve Remael'in (2007) de vurguladiğı görsel-işitsel çeviride küfürden kaçınma eğiliminin yaygın olduğu tespitini doğrulamaktadır. Ancak burada gözlemlenen, küfürden kaçınmaya ek olarak örtmecenin göz ardı edilmesidir. Dolayısıyla hem küfür hem de örtmecenin birlikte çeviride verilmemesi, dizinin kurmaca dünyasının eksik ve yanlış bir şekilde temsil edilmesi sonucunu doğurmaktadır.

Buna örnek olarak, dizide küfürlere uygulanan örtmecenin anlatıdaki işlevinin öne çıktığı bir sahne verilebilir. Bu sahnede dizinin tasarımında "fuck" sözcüğünün "çatal" anlamındaki "fork" sözcüğüne dönüşmesindeki motivasyon, fantastik bir anlatı yapısıyla kurgulanmıştır. İyi Yer'de 
Eleanor'un kendisine verilen çöp toplama görevini tamamlamaması ve bu konuda yalan söylemesi sonrasında birden gökten bazı nesneler yağmaya başlayınca Eleanor "Oh, fork!” cümlesiyle şaşkınlık ve korku içeren bir tepki gösterir. Bu kaos esnasında, gökten "fork" sözcüğünü temsil eden büyük bir çatalın İyi Yer'e düştügüüü görürüz. Dizinin oluşumundaki ikonografik kodlar incelendiğinde gökten düşen en büyük obje olan bu çatal, cehennemi ve kötülügü temsil eden şeytanın elindeki üç başlı dirgeni çağrıştıran bir simge olarak yorumlanabilir. Çatalı gördüğünde Eleanor'un "Oh, fork" diyerek bir taraftan objenin adını söylerken diğer taraftan küfretmesi örtmecenin motivasyonuna gönderme yapmaktadır. Özellikle anlatının dramatik bir boyuta ulaştığı bu sahnede dildeki yaratıcılıkla birlikte fantastik boyutun bütünlüklü işlevi öne çıkmakta, bunlarla paralel hareket eden örtmecenin işlevi gözler önüne serilmektedir. Bu sahnenin çevirisi incelendiğinde "Oh fork" ifadesinin altyazıya "Hay lanet", dublaja ise "Oh hadi" biçiminde aktarıldığı ve dolayısıyla örtmecenin motivasyonunun göz ardı edildiği ve gökten neden çatal düştüğü konusunda erek kitlenin dizinin görsel kodlarını okumakta zorlanabileceği görülmektedir.

Örtmeceli küfrün çevirisinin erek metinde yer almamasının nedenlerini sorguladı̆̆ımızda birkaç husus dikkat çekmektedir. Örtmeceli küfrün Türkçede görünmez kılınmasının daha sıklıkla görüldüğü örneklerin bir kısmının, İngilizce ile Türkçe arasındaki yapısal farklardan olduğu iddia edilebilir. Türkçenin, çekimli bir dil olan İngilizceden farklı olarak eklemeli bir dil olması, sözcük tür ve kullanımının farklılık göstermesi, dillerin sözdizimi özelliklerinin birbirine zıt olması çeviriyi kimi zaman zorlayabilmektedir. Bunun yanı sıra metnin bağlamı ve dillere özgü küfürlerin kalıplaşmış ifadeler içinde kullanımı da çeviri kararlarında etkili olabilecek unsurlardır. Sözgelimi "fork" sözcüğünün yine pekiştireç işleviyle kullanıldığ1 "but I forkin' nailed it” (S1B2; ZK 20:57) ifadesinin altyazıda “Evet, ama başardım”, dublajda “Evet, ama süper söyledim" biçiminde çevrilmesi, yapısal farklardan kaynaklanan durumlara örnek olarak verilebilir.

Küfürlerin yok sayılmasının nedenleri, diğer taraftan kullanılan görsel-işitsel çeviri türüne bağlı olabilmektedir. Örneğin, dublajın en önemli özelliği, izleyiciye kendi dilinde doğal bir ürün izlenimi vermesi ve bir gerçeklik yanılsaması oluşturmasıdır. Bunun sağlanabilmesi için işitsel düzgü ile görüntülerin belli bir uyum içinde olması beklenir. Bu nedenle dublajın en önemli kısıtlılıklarının başında eşleme ${ }^{2}$ (senkron) gelir. Eşlemeler kaliteli bir dublajla ilgili önemli parametrelerdir. Eşleme gibi teknik kısıtlılıklarının dışında Chaume, iyi bir dublajda güvenilir ve gerçekçi bir konuşma dilinin kullanılmış olmasına ve görüntü-diyalog arasında anlam bütünlüğü sağlayan uyuma (cohesion) işaret eder (2012, s. 15-16). Altyazı çevirisinde ise daha önce belirttiğimiz üzere hem sahne değişimi hem de izleyicinin okuma hızı dikkate alınarak düzenlenen altyazının ekranda kalma süresi, ekranda yer alabilecek en fazla karakter sayısı ve görüntü-altyazı senkronu gibi kısıtlılıklar söz konusudur. Görsel-işitsel çeviri türünün altyazı veya dublaj

\footnotetext{
${ }^{2}$ Eşleme türlerinin başında ise karakterlerin ağız ve dudak hareketlerinin işitsel düzgüyle uyumunu ifade eden dudak eşleme (phonetic synchrony) ve diyalogların başlangıç ve bitişinde görüntü ses uyumunu ifade eden zamansal (isochrony) eşleme gelir (Oğuz, 2018, s. 107-111; Günay- Köprülü, 2016, s. 492-493). Dudak ve zamansal eşlemenin yanı sıra işitsel düzgüyle karakterlerin beden dili, jest ve mimiklerinin örtüşmesi gerektiğini savunan bedensel eşleme (kinesic/kinetic synchrony) (Whitmen-Linsen, 1992, s. 33) ve işitsellerin dışında anlam tamamlayıcı ögelerden oluşan dil ötesi eşleme (paralinguistic synchrony) (Herbst, 1994, s. 52) çeviri sırasında göz önünde bulundurulan eşleme türleridir.
} 
olmasına bağlı olarak küfürlerin yok sayılmasında belirleyici olabileceğini hesaba kattığımızda birkaç örnek göze çarpmaktadır.

Sözgelimi "fork" sözcüğünün isim olarak kullanıldığ diğer örnekte, ağzı bozuk bir karakter olan Eleanor, Chidi'nin ahlak profesörü olduğunu öğrendiği bir sahnede, şaşkınlığını belirtmek için ifadeyi uzatarak, ağzı yaygın bir biçimde "Motherforker" (S1B1; ZK 12:31) ifadesini kullanmaktadır. İlgili ifade Türkçeye altyazıda "yok artık", dublajda ise "hadi ordan be" olarak çevrilmiştir. Yakın çekimdeki sahnede altyazı açısından bir sorun görünmemekle beraber dublajda "hadi ordan be" ifadesinin dudak eşlemesi bakımından seçilmiş olabileceği düşünülmektedir. Zira, bu sahnede Eleanor küfrü uzatarak ve vurgulayarak söylediği için "motherforker" sözcüğündeki "o" yuvarlak geniş ünlüsü, hâliyle karakterin dudaklarının ve ağzının verdiği görüntüyü etkilemektedir. Çevirmenin dudak eşlemeye göre tercih yapmış olabileceğini düşündüren bir başka örnek, hemen bu sahneden önce yine Eleanor'un şaşkınlık ve ünlem ifadesi olarak kullandığ1 "What the fork?" (S1B1; ZK 11:14) cümlesinin altyazıda "Bu da ne?", dublajda "Ah, hadi ordan be!" biçimindeki çevirisidir. Bu sahnede yine yakın çekim görülmektedir ve dudak uyumu mevcuttur.

Dublajdaki en önemli kısıtlayıcı unsurun dudak eşleme ve izokronik eşleme (ağız) olmasından hareketle çeviri türü olarak dublajın çeviri kararlarını etkilediği diğer bir örnek ise bulgular bölümünde F2 kategorisinde ele aldığımız "We need a distraction. Right the fork now" (S1B4; ZK 15:16) ifadesinin çevirisidir. Sahneyi incelediğimizde karakterin görüntüde (G) olduğu ve dolayısıyla ağız hareketlerinin görülebildiği bölümde ağız bırakmamak için çevirmenin metne müdahale edip ekleme yaptığını ve oluşabilecek boşluğu telafi cümlesiyle kapattığını görüyoruz. Sözünü ettiğimiz birkaç sahnenin çevirisinde gördüğümüz gibi dublaj, doğası gereği orijinal sesin duyulmasına imkân vermeyen özelliğiyle çevirmenin daha rahat çeviri kararı verebildiği bir görsel-işitsel çeviri türü olarak karşımıza çıkıyor. Çevirisini incelediğimiz bölümlerin altyazısını incelediğimizde ise karakter sayısı, ekranda kalma süresi ve satır sayısı olarak çeviriyi kısıtlayacak uzunlukta bir diyalog bulunmamaktadır.

Dizinin orijinali ile Türkçe çevirisi arasında örtmeceli küfürlerin aktarılma biçimlerinde tespit edilen tutarsızlıklar dizinin yaratım süreci ile çeviri sürecinin yürütülmesinde farklı koşulların devrede olmasına bağlanabilir. Buna göre, dizi tek bir yaratıcı ekibin elinden çıarken ve senaryodaki devamlılık bu ekip tarafından sağlanırken, çeviri sürecinde her bir bölümün farklı çevirmenler tarafından çevrildiği ve örtmecenin aktarılma biçimlerinde devamlılık gözetilmediği görülmektedir. Zira bunun etkisi aynı diyalogun farklı şekillerde çevrildiği sahnelerde fark edilebilmektedir. Örneğin, dizinin birinci sezonu Eleanor'un hafızasının silinmesiyle ve gözlerini açtığında hiçbir şeyi hatırlamadığı görüntülerle son bulur. Sezon sonu bölümünde Eleanor'un elinde yalnızca üzerinde "Chidi" yazan bir kâğıt vardır. Eleanor'un bunun ne anlama geldiğini sorgularken kullandığ1 "What the fork is a Chidi?" cümlesi Türkçeye altyazıda "Chidi denen bu fok da neyin nesi? Neden 'fok' diyemiyorum?" olarak ve dublajda "Söktür, Chidi de ne demek be? Niye 'söktür' diyemiyorum? (G)" (S1B13; ZK 21:16) olarak çevrilmiştir. Burada farklı şekillerde de olsa altyazıda ve dublajda "fork" örtmeceli küfrü orijinalinde olduğu gibi Türkçeye örtmece muhafaza edilerek aktarılmıştır. Ancak, ikinci sezonun başında seyircilere önceki bölümleri 
hatırlatma mahiyetindeki özet görüntülerinde aynı sahneler farklı biçimde çevrilmiştir. İkinci sezondaki çeviriler altyazıda "Chidi ne sirkim demek oluyor? Neden 'sirkim' diyemiyorum?", dublajda ise "Söktür Chidi de ne lan? Niye 'söktür' diyemiyorum? (G)" (S2B1; ZK 01:56) biçimindedir. Dolayısıyla, burada çeviride tespit edilen tutarsızlı̆̆ın ve devamlılık eksikliğinin çevirinin yürütülme sürecinde farklı çevirmenler arasında iletişimin olmaması ve metindeki bu tür yaratıcı detaylarla ilgili bilgi aktarımının sağlanmasına dikkat edilmemesi gibi hususlardan kaynaklandığ 1 iddia edilebilir.

Buna ek olarak, daha önce belirtildiği üzere dizi, İyi Yer ve Kötü Yer gibi birkaç farklı mekânda geçmektedir ve bu durum, küfürlerin örtmeceye uğratılıp uğratılmamasıyla izleyiciye hissettirilmektedir. Kötü Yer'de geçen sahnelerden birinde Eleanor'un partneri olan Chidi'ye filtresiz bir biçimde söylediği "Lie your ass" ifadesi (S1B11; ZK 13:35), Türkçeye altyazıda ve dublajda "Yalan söyle gitsin" olarak verilmiştir. Burada filtreli alan olarak tanımladı̆̆ımız İyi Yer'de "ash" olarak filtrelenen "ass" sözcüğünün ölçünlü dil kullanımı ile çevrildiği izlenimi veren bir çıkarma/silme yolu seçildiği görülmektedir. Sıradan bir küfür çevirisinden farklı olarak, örtmeceli küfür kullanımının olduğu bu metinde küfrün aktarılmasında tonun yumuşatılması veya ölçünlü dil kullanımı gibi bir yönteme başvurulması, dizide filtreli alan ile filtresiz alan farkı olduğunu ortadan kaldırma riski taşımaktadır. İyi Yer'de filtreli alanda küfürlerin çevirisinde kullanılan "hadi oradan", "vay be", "yok artık" gibi günlük ifadelerin, Kötü Yer gibi filtresiz bir alanda kullanılan ifadelerle aynı olması, konuyu dizinin mizah etkisinin izleyiciye ulaşabilmesi açısından tartışmaya açık hale getirebilmektedir. Örneğin, Eleanor'un Tahani'nin evine ilk kez gittiği ve evi gördüğü sahnede evin çok büyük ve güzel olması karşısında (S1B1; ZK 13:57) küfür kullanmadan sıradan bir şaşırma ifadesi olarak "No way" dediği görülmektedir. Bu ifadenin "yok artık" ve hadi be" biçiminde, birkaç dakika önce küfür çevirisinde kullanılan ifadelerde olduğu gibi çevrilmiş olması izleyicinin küfürlü ve küfürsüz kullanımları ayırt edememesine ve dolayısıyla mizahı algılayamamasına yol açabilmektedir.

\section{SONUÇ}

Çalışmamızda, 2016-2020 yılları arasında dört sezon olarak yayınlanan dizinin ilk üç sezonunda İngilizcede ve Türkçe çevirisinde örtmeceli küfürlerin ne şekilde oluşturulduğu, özellikleri ve metin içindeki işlevleri karşılaştırmalı olarak incelenmiştir. Dizide küfür filtresinin kullanıldığı diyaloglar baz alınarak çıkarılan listeye göre dizinin çevirisinde tespit edilen küfür filtreleme(me) türleri dört gruba ayrılmıştır. Dizinin yaratıcı ekibinin örtmece oluşturma biçiminde yöntemsel farklılık görülse de altyazı ve dublaj çevirmenlerinin küfürleri örtmeceli olarak Türkçeye aktarırken yeniden modelleme yöntemine başvurmuş olması bir ortak nokta olarak dikkat çekmiştir. Bu ortak nokta değerlendirilirken, küfür çevirisinde yaygın bir şekilde görülen çıkarma veya silme gibi stratejilerin bu dizi özelindeki çeviri sürecinde kullanılmasını zorlaştıran ve tartışmaya açan bir faktör, çevirmenin küfür çevirisinden ziyade sözcük oyunu içeren sansürlü küfür çevirisi ile karşı karşıya kalması ve bazı durumlarda dizinin kurmaca dünyasında küfür filtresine doğrudan gönderme yapan diyalogların geçmesi olarak yorumlanabilir. Dolayısıyla, küfür kullanımının, filtrelenmiş olarak da olsa, karakter temsiline ek olarak mizah etkisi oluşturma 
gibi kilit bir işlevinin bulunması, bu dizide çevirmenin yaratım sürecini belirlemektedir. Bu nedenle, bu işlevin göz ardı edilmesi sadece çeviride örtmeceli küfürlerin yok sayıldığı örneklerde değil, dizinin orijinalinde örtmeceli küfür kullanımı olmadığı halde çeviride küfür ve/veya örtmecenin eklendiği bölümlerin varlığı ile de kendini göstermektedir. Bu anlamda, örtmeceli küfürlerin Türkçeye çevirisinde kaynak metinde olduğu gibi bir tutarlılık arz etmemesi, diller arasındaki yapısal farklılıklar ve kullanılan görsel-işitsel çeviri türüne bağlı olabileceği gibi, dizinin yaratım süreci ile çeviri sürecinin her iki dilde farklı koşullarda yürütülmesi de önemli bir etken olarak tartışılmalıdır. İyi Yer'deki küfür filtresinin varlığının dizinin sadece birinci sezonunun ilk bölümünde açıklandığı düşünüldüğünde, örtmeceli küfürlerin çevirisindeki tutarlılık sorununda Netflix'in çevirmenler ile çalışma politikasının rol aldığı da iddia edilebilir. Yayınlanan her bir bölümün açlış jeneriğinde altyazı çevirmeni olarak farklı bir çevirmenin adının yer alması, dublaj çevirisinden farklı olarak özellikle altyazı çevirisinde devamlılık gözetilmediğini ve bölümleri çeviren farklı çevirmenler arasında iletişim olmadığını öne sürmeyi mümkün kılmaktadır. Bu çalışmada tespit edilen ve tartışmaya açılan noktalar, gelecekteki çalışmalarda İyi Yer gibi çeviri sürecinde devamlılığın özellikle önem arz ettiği görsel-işitsel metinlerin çevirisinde, Netflix gibi platformların çeviri politikalarının belirleyiciliğini tespit etmek amacıyla çevirmenler ile yapılacak mülakatlar ile daha kapsamlı bir şekilde ele alınabilir. Böylece, çeviri üzerinden yaptığımız tespitler daha geniş bir bağlama oturtularak Türkiye'deki dijital platformlardaki çeviri üretim dinamiklerine ve bu dinamiklerin çevirinin kalitesine ve tutarlılığına etkisine dair veri sunabilecektir.

\section{KAYNAKÇA}

Allan, K., Burridge, K. (1991). Euphemism and dysphemism: language used as shield and weapon, New York: Oxford University Press.

Allan, K., Burridge, K. (2006). Forbidden words: taboo and the censoring of language. Cambridge: Cambridge University Press.

Allan, K. (2012). "X-phemism and creativity." Lexis 7.

Andersson, L. G., Trudgill, P. (1990). Bad language. Oxford: Basil Blackwell.

Ávila-Cabrera, J. J. (2015). "An account of the subtitling of offensive and taboo language in Tarantino's screenplays." Sendebar: Revista de la Facultad de Traducción e Interpretació, 26, 3756.

Bednarek, M. (2019). “'Don't say crap. Don't use swear words.' - Negotiating the use of swear/taboo words in the narrative mass media." Discourse, Context E Media, 29, 1-14.

Bricker, T. (20 Eylül 2016). The Good Place's Kristen Bell and Ted Danson Reveal Their Forkin' Favorite Alternative Curse Words. https://www.eonline.com/news/796046/the-good-place-skristen-bell-and-ted-danson-reveal-their-forkin-favorite-alternative-curse-words $>$ (erişim 15.03.2021).

Chaume, F. (2004). "Discourse markers in audiovisual translating." Meta 49(4), 843-855.

Chaume, F. (2012). Audiovisual translation: Dubbing. London \& New York: Routledge.

Chen, C (2004). "On the Hong Kong Chinese subtitling of English swearwords." Meta: journal des traducteurs / Meta: Translators' Journal 49(1), 135-147. 
Delabastita, D. (1989). "Translation and mass-communication: Film and T.V. translation as evidence of cultural Dynamics." Babel, 35(4), 193-218.

Devellioğlu, F. (1980). Türk argosu. Ankara: Aydın Kitabevi Yayınları, 6. Baskı.

Díaz Cintas, J. (2001). "Sex, (sub)titles and videotapes." Traducción subordinada II: el subtitulado (inglés - español/galego). Lourdes Lorenzo García and Ana María Pereira Rodríguez (eds), 4767. Vigo: Universidad de Vigo.

Díaz Cintas, J., Remael, A. (2007). Audiovisual translation: subtitling. Manchester: St Jerome.

Farghal M. (1995). “Euphemism in Arabic: A Gricean interpretation.” Anthropological Linguistics, 37, 336-378.

Fernández Dobao, A. M. (2006). “Linguistic and cultural aspects of the translation of swearing: The Spanish version of Pulp Fiction." Babel, 52(3). 222-242.

Greenall, A. K. (2011). The non-translation of swearing in subtitling: loss of social implicature? In Audiovisual Translation in Close-up: Practical and Theoretical Approaches. Adriana Şerban, Anna Matamala, and Jean-Marc Lavaur (eds.), (pp. 45-60). Bern: Peter Lang.

Günay-Köprülü, S. (2016). “Film çevirisinde fonetik eşleme.” ODÜ Sosyal Bilimler Araştırmaları Dergisi (ODÜSOBIAD), 6(15), 488-503.

Hazen, K. (Temmuz 2020). "Zounds! What the fork are minced oaths? And why are we still fecking using them today?" The Conversation https://theconversation.com/zounds-what-thefork-are-minced-oaths-and-why-are-we-still-fecking-using-them-today-141423 (erişim 15.03.2021)

Herbst, T. (1994). Linguistische Aspekte der Synchronisation von Fernsehserien: Phonetik, Textlinguistik, Übersetzungstheorie. Linguistische Arbeiten; 318. Tübingen: Niemeyer.

Keyes, R. (2010). Euphemania. Our Love Affairs with Euphemisms.

Lantto, H. (2014). “Code-switching, swearing and slang: The colloquial register of Basque in Greater Bilbao." International Journal of Bilingualism. 18(6), 633-648.

McEnery, T. (2005). Swearing in English: Bad language, purity and power from 1586 to the present. London/New York: Routledge.

Oğuz, D. (2018). “Görsel-işitsel çeviri: dublaj ve göstergebilim.” Hacettepe Üniversitesi Çeviribilim ve Uygulamalarn Dergisi, 24, 99-116.

Oğuz, D. (2017). “Altyazı çevirisinde bir kısıtlama: senkron.” Turkish Studies International Periodical for the Languages, Literature and History of Turkish or Turkic, 12(7), 275- 290.

Pujol, D. (2006). "The translation and dubbing of 'fuck' into Catalan: The case of From Dusk till Dawn." The Journal of Specialised Translation, 6, 121-133.

Soler Pardo, B. (2013). "Translating and dubbing verbal violence in Reservoir Dogs. Censorship in the linguistic transference of Quentin Tarantino's (swear)words." The Journal of Specialised Translation, 20, 122-133.

Thawabteh, M. A. (2012). “The translatability of euphemism and dysphemism in Arabic-English subtitling." Lexis [Online], 7, 145-156.

Trupej, J. (2019). "Avoiding offensive language in audio-visual translation: A case study of subtitling from English to Slovenian." Across Languages and Cultures, 20(1), 57-77.

Whitmen-Linsen, C. (1992). Through the Dubbing Glass: The synchronisation of American motion pictures into German, French and Spanish. Frankfurt am Main: Peter Lang. 


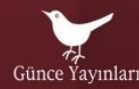

Prof. Dr. Önder Göçgün

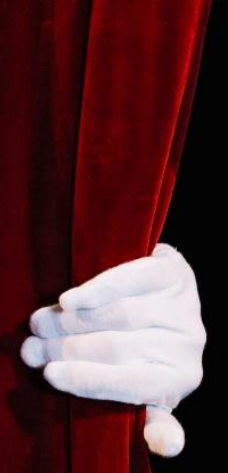

TIYYATRO DENEN HAYAT

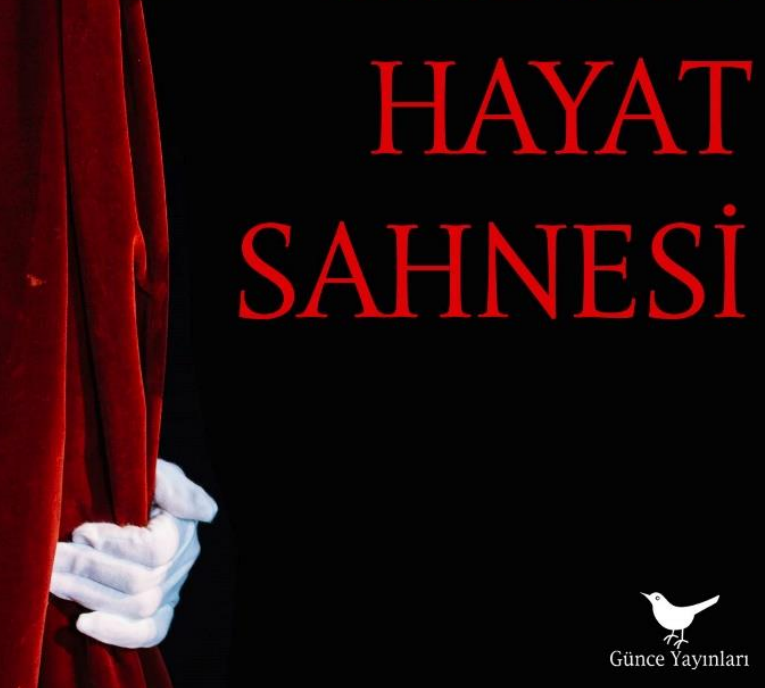

MUIIARREM DAYANC OKTAY YIVLI MACI'I BALIK MAIIMU'I BABACAN SLVIM SLERMEI
YASFMIN MUMCU BLDI் KOÇАKOĞLU NILÜLLLR ILLHAN MAKSUT YIĞITBAS SLL $\triangle M I I L \Lambda N$

\section{EDEBIYATINDA

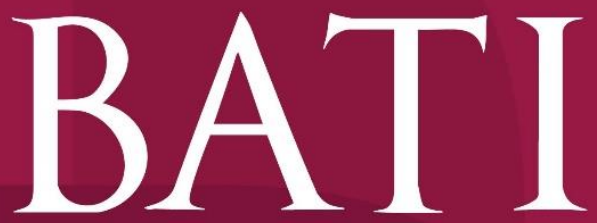 \\ EDEBIYATINDA
AKIMLAR \\ $\underset{\substack{\text { EDEBIYATINDA } \\ \text { AKIMLAR }}}{\mathrm{B} A T \mathrm{~T}}$}

editör

OKTAY YIVLI

HATICE FIRAT

YASEMIN MUMCU

OKTAY YIVLI

OĞUZHAN KARABURGU

BERNA AKYÜZ SIZGEN

NILÜFER ILHAN
ÜMMÜHAN TOPÇU

SEFA YÜCE

HANIFI ASLAN

METIN AKYÜZ

MEHMET SÜMER
YAKUP ÖZTÜRK
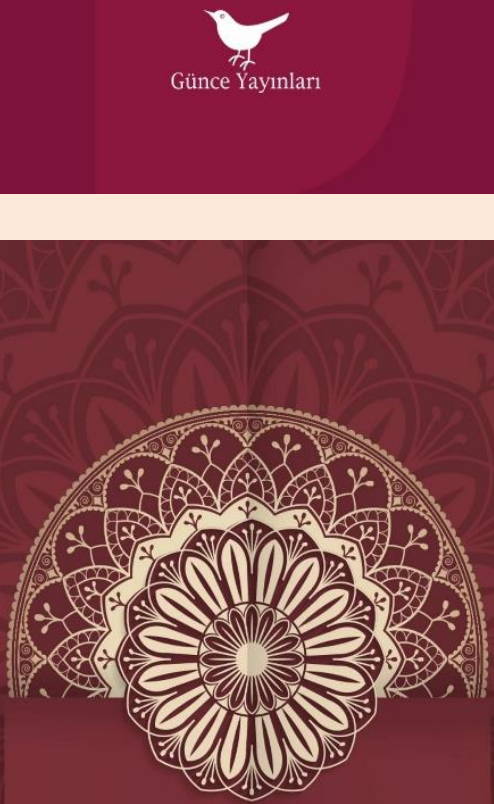

PROF. DR. ÖNDER GÖÇGÜN

$$
\begin{gathered}
\text { Türk } \\
\text { Tasavvuf } \\
\text { Siini }
\end{gathered}
$$

AÇIKLAMALI VE YORUMLU ÖRNEKLERLE 